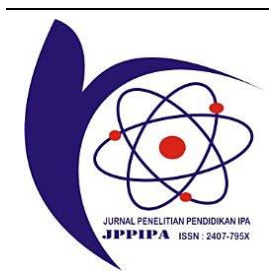

\title{
Analysis of the Needs of Developing Teaching Materials in the Form of STEM-Based Web Modules Using Scaffolding
}

\author{
Menza Hendri ${ }^{1}$ Dian Pertiwi Rasmi², Winda Ananda ${ }^{3 *}$, \\ Program Studi Pendidikan Fisika, Universitas Jambi, Jambi, Indonesia
}

DOI: $10.29303 /$ ippipa.v7iSpeciallssue.1019

\section{Article Info}

Received: August 4th 2021

Revised: November 18th 2021

Accepted: November 30th 2021

\begin{abstract}
Since the Coronavirus disease (COVID-19) pandemic, the world of education has been affected by the application of a learning system that is carried out in a blended learning manner. Therefore, this study aims to develop teaching materials in the form of a STEM-based web module using scaffolding to assist the learning process during the covid 19 pandemic. The development of a STEM-based web module using scaffolding is carried out using the ADDIE development model (Analysis, Design, Development, Implementation, Evaluation). Data were obtained through interviews with physics teachers. Based on the results of interviews with teachers at one of the senior high schools in Batanghari district, it is known that in offline learning, printed books from the school library are still used. Therefore, we need an electronic module that can be accessed anytime and anywhere to facilitate the learning process. So that researchers will develop a STEMbased web module using scaffolding on straight motion physics material for class $\mathrm{X}$ high school. The product produced is in the form of a web containing material for straight motion physics class X SMA/MA based on STEM using scaffolding.
\end{abstract}

Keywords: web module; STEM; Scaffolding

Citation: Hendri, M. ., Rasmi, D. P. ., \& ananda, W. .-. (2021). Analysis of the Needs of Developing Teaching Materials in the Form of STEM-Based Web Modules Using Scaffolding. Jurnal Penelitian Pendidikan IPA, 7(Speciallssue), 139-144. https://doi.org/10.29303/jppipa.v7iSpeciallssue.1019

\section{Introduction}

The impact of the spread of covid-19 causes the learning process to be carried out in a blended learning manner. The learning process is carried out in a blended learning manner to prevent the spread of COVID-19 which is increasing every day. The learning process by applying Blended learning is a challenge for educators and students. This is in line with (Siahaan, 2020) who said that Due to interaction restrictions, the Indonesian Ministry of Education has also issued a policy to close schools and use online systems to replace the teaching and learning process (KBM). By using this online learning system, sometimes students and teachers encounter various obstacles.

Blended learning is learning that combines faceto-face learning (direct) and online learning or commonly known as online and offline learning. This is in line with (Rizkiyah, 2013) Blended learning combines aspects of web/internet-based learning, video streaming, synchronous audio communication, and asynchronous 1 lent learning is learning that utilizes information technology in the form of e-learning as a medium in delivering learning and increasing student motivation with more modern and interesting learning.

One of the challenges the problem faced by educators is that they must be able to adapt to various technologies used in the learning process. And also educators must be more innovative and creative to realize the learning process. In addition to educators, students also have their challenges, namely, students find it difficult to understand the learning materials explained online, especially in physics. Many students think that Physics is a difficult subject because it is abstract and filled with formulas so that it is difficult to understand if only explained online.

Physics is one of the subjects that deal with various scientific concepts, some of which can be found 
in everyday life. physics plays an important role in explaining various phenomena that occur in the universe (Maison et al., 2018). This is in line with (Astuti et al., 2017) Physics material is material related to everyday life, so teachers are required to be able to explain the concept in a real form. Different from (Athhibby, 2015) which states that physics is a science that studies the parts of nature and the interactions that exist in it. It is often heard that Physics subjects are scary subjects, not only students, even the general public have the same explanation for physics subjects. Physics is very closely related to everyday life without us realizing one example of technology from the application of physics is electricity, computers, television, radio, and others.

One effort to make it easier for students in the physics learning process is to develop an electronic module. Modules are alternative materials that can be developed to support the student learning process (Sumiati et al., 2018). Modules are teaching materials that are systematically arranged, the language used is easy for students to understand, making it easier for students to achieve clearly defined goals (Setiawati et al., 2013). Along with advances in technology, print modules innovate into electronic modules because users of electronic modules are more practical.

Electronic modules or commonly called Emodules are the latest innovations from printing modules. The electronic module can be accessed with the help of a computer that is integrated with software that supports electronic module access (Priatna et al., 2017). E-module is a form of material in digital form, which consists of text, images, or both containing digital electronics material followed by simulations that can and are suitable for use in learning (Herawati \& Muhtadi, 2018). This means that by using electronic modules, students and educators can make learning more interactive for students to be able to relate the knowledge gained to real life, one of them is to use the STEM (Science, Technology, Engineering, and Mathematics) approach. STEM (Science, Technology, Engineering and Mathematics) education is currently a science learning option that can establish a generation that can overcome the challenging 21st century. The STEM approach means combining 4 elements of education, namely science (S), technology (T), engineering (E), and Mathematics (M) by focusing on solving concrete problems by presenting topics in daily activities that are close to students and how students feel (Subramaniam et al., 2012). In general, the application of STEM learning can encourage students to design, improve and use technology, hone cognitive, manipulative, and effective, and apply knowledge. Problem-solving related areas using technology. The application of STEM can improve students' academic and non-academic achievements (Permanasari, 2016).

In addition to being equipped with the STEM learning model, the module will also be used as independent teaching material for students so that there is a need for scaffolding to assist students in using the module. Scaffolding in a module or e-book is done to students who experience errors in solving story problems. Pushing with Scaffolding refers to Scaffolding levels. Several forms of scaffolding given can be in the form of level 2, namely explaining (explaining), reviewing (re-examining), and restructuring (rebuilding understanding) (Rahayuningsih \& Qohar, 2014). This is in line with the Scaffolding Method which can increase students' mastery of physics concepts optimally. The provision of scaffolding is structured at the beginning of learning and then gradually activates students to learn independently (Moong et al., 2020). So that the provision of scaffolding can help students learn independently.

In addition, with the development of technology, students already have laptops and Android or Smartphones that are used in everyday life. So to take advantage of the technology that is the challenge of the 21st century, the modules are packaged using the web so that users can access them on laptops and Android or Smartphones anytime and anywhere. website or abbreviated as the web, can be interpreted as a collection of pages consisting of several pages that contain data in the form of digital information in the form of text, photos, videos, audio, and other animations provided via an internet connection (Patra et al., 2018). Website is an acronym for the World Wide Web (WWW). This WWW information is stored on a webserver to be accessed from a network browser first, such as Internet Explorer or Mozilla Firefox. A website is a collection of pages containing information that is connected by a network and stored on a web server (Fridayanthie \& Mahdiati, 2016).

Based on an interview conducted with a physics teacher at a State High School in Batanghari, the online learning process, especially physics subjects, is carried out using Google Classroom. While the teaching materials used are printed books and sometimes combined with e-books. However, this e-book is only for reference, and the most frequently used are printed books. And have never used the module. For class $X$ Physics, especially Straight Motion, it is difficult to teach students, especially the GLBB concept. So if teaching materials are developed that can facilitate the learning process during the COVID-19 pandemic, I support it, he said.

Based on the background described above, the researchers took a solution by developing teaching 
materials. The teaching materials developed are web modules with attractive designs and content. The Web Module can be used as teaching material for educators and students on straight-motion material. The purpose of this study was to analyze and explore the needs of teachers for the development of learning media in the form of STEM-based electronic modules using scaffolding in an attractive, easy-to-use, and useful web form in the learning process.

\section{Method}

This research was conducted by analyzing the needs of teachers in one of the SMA N in Batanghari. This research uses the type of research and development (Research and Development). The Research and development (R\&D) method is a research method that produces a product in a certain professional field, followed by several by-products, and has the effectiveness of the product (Budiyono, 2011). The development design used by the researcher is the ADDIE development model (Analysis, Design, Development or Production, Implementation or Delivery and Evaluations). The researcher chose this model because the ADDIE model is a general learning model and is suitable for development research (Tegeh et al., 2015).

The first stage of this development research is the analysis stage. In this needs analysis, there are several activities, namely: Analyzing existing problems, Setting Goals, Student Analysis, Analysis of Available Resources, and Material Analysis.

Table 1. Analysis of needs for physics teacher responses

No Question

1 What curriculum is used in schools?

2 How to use technology in learning activities? Like the use of smartphones, computers?

3 What are the teaching materials used during online learning?

4 Do you use modules during the learning process?

5 Are there online printed books (e-books) or online modules (emodules) during the teaching and learning process during the COVID-19 period?

6 Do you think that the material for straight motion physics is difficult when it is taught in class?

7 When teaching straight motion, what difficulties/obstacles did you experience?

8 Is there any practicum that is done on the material of gerak lurus?

9 If there is no electronic module (online) is there a need for an electronic module to support the student learning process during the Covid-19 period?

10 Do you know about web-based e-modules (electronic modules) with a STEM approach through scaffolding?

11 Are you interested in developing teaching materials in the form of a STEM-based web module using scaffolding on straight motion material?
At the stage of analyzing the existing problems, the stage carried out by researchers is to find out the problems faced at school. It aims to find out and identify problems related to the learning process. This stage is carried out with initial observations carried out by interviews with physics subject teachers so that the E-learning modules designed in the future can be used to solve problems faced at school and faced by educators in the learning process.

Next is to set the objectives of the learning module design. The learning modules that are designed later must be adjusted to the learning objectives that students want to achieve so that following KI and KD.

Furthermore, this analysis aims to identify the resources that will be needed in development. This analysis is also used to determine whether the selected school as the object of research is willing to assist the research process and determine the human resources that support the module development process using the ADDIE model.

The last is Material Analysis. At this stage, the researcher will examine the curriculum applied in schools and the researcher will analyze the KI, KD, and indicators that are the reference in developing the product.

\section{Result and Discussion}

Based on the results of interviews conducted with Physics Learning Teachers regarding the need for teaching materials and the importance of developing this product, it can be seen in table 1 .

\section{Answer \\ 2013 Curriculum \\ For online learning at SMA N 1 Batanghari using Google \\ Classroom \\ Printed books provided in the school library \\ Do not use modules because modules are rarely encountered}

Sometimes use e-books in addition (references)

If only taught in theory, it will be difficult

For GLB, it is still easy to say, but for GLBB it is difficult to cultivate the concept.

No practicum because during the pandemic, students study from home

It is necessary because it can facilitate the learning process

I have received information about the e-module from a fellow teacher. But it has not been used to its full potential. And for STEM I've read it but have not understood it clearly. Interested, because it can facilitate the learning process, especially when online like this. 
Based on interviews that have been conducted, it shows that the school has implemented the 2013 curriculum which is based on the Regulation of the Ministry of Education and Culture (Permendikbud) No. 81 A regarding curriculum implementation, explains that learning in the 2013 Curriculum uses a scientific approach and is student-centered. Therefore, students are required to be independent in learning so that in this case a module as a companion in the learning process is needed.

Furthermore, the use of technology in learning activities began to be used during online learning recently, namely the use of Google classroom in learning. While the teaching materials used are printed books from the Ministry of National Education provided by the school library. And never use the Module because until now there has been no module, only e-books as an additional reference. For e-modules, it has been discussed with other fellow teachers, but the existence of modules is rarely encountered and has not been utilized optimally. So if the development of electronic modules is carried out to facilitate the learning process, I am interested, he said.

One of the positive impacts of the COVID-19 pandemic in the world of education is that without us

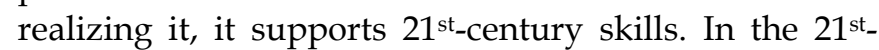
century, students are also required to be skilled in the use of technology. In terms of using technology, the educator also said that the majority of students have laptops, android smartphones that can be used if needed during learning for learning purposes, and also so far educators have never used E-Modules. However, educators are very interested in holding media such as STEM-based Web Modules using Scaffolding.

This STEM-based web module using Scaffolding has advantages because this web module contains material that is equipped with images, videos, and other animations that attract students' attention to make learning more interactive. In addition, this web module can be used as independent teaching material for students because students can access this web module anytime and anywhere so that its use is more practical than the print module.

These teaching materials are arranged using the STEM approach so that the physics concepts are directly related to everyday life. This is in line (Yulia \& Ramli, 2019) Through the STEM approach, students do not just memorize concepts, but students have an understanding of how these concepts are obtained and understand science concepts and their relationships in everyday life. The purpose of applying STEM learning is of course so that students can integrate science, technology, and mathematics lessons into a single unit that becomes the basis for students to practice critical thinking in solving problems of everyday life (Supriyatun, 2019).

In addition to using STEM on the web, this module also contains scaffolding which can help students learn independently. Theoretically, scaffolding can improve the quality of the teaching and learning process of Physics which in turn will improve student achievement. Some of the advantages of using scaffolding are that it can improve student investigation and performance, keep students from feeling failed, and can bridge students' difficulties in learning (Rahmatiah et al., 2016).

Furthermore, when teaching the material for straight motion physics class $X$, difficulties were found when explaining concepts in GLBB. so that if a web module is developed that not only contains material but is also equipped with pictures, videos, and simple practicums, it can make students more understanding and interested in understanding learning.

Based on the results of interviews conducted, this is used as a reference in developing teaching materials. The teaching materials developed are in the form of a STEM-based web module using scaffolding on straight motion physics material for SMA/MA class $X$. The developed modules are arranged according to the curriculum, and the use of this web module is more practical because it can be used anytime and anywhere by students as independent teaching materials for students.

Thus, this research will produce teaching materials in the form of STEM-based web modules using scaffolding on straight motion materials for SMA/MA X classes to facilitate the learning process during the Coronavirus disease (COVID-19) and can be used as independent teaching materials for students at home.

\section{Conclusion}

This study seeks to find a study of teacher needs analysis that contains teaching materials. The results of this study are used to develop a teaching material product in the form of a STEM-based module using scaffolding packaged in the form of a web application. Based on the Needs Analysis that has been carried out, it is known that the teacher needs electronic teaching materials that attract students' interest in learning during the Coronavirus disease (COVID-19) pandemic and can be used by students as independent and guided teaching materials. Based on this, it can be used as a reference in the next development process, namely developing teaching material in the form of a STEMbased module using scaffolding. Products made in web form aim to be practical in use while using STEM-based 
products to suit current technological developments.

\section{Acknowledgements}

This research can be carried out properly and smoothly thanks to the cooperation and assistance of various parties. For this reason, the researchers would like to thank the Sma Negeri 1 Batanghari school, especially the teachers in the field of physics studies who have provided good cooperation in this research.

\section{References}

Astuti, I. A. D., Sumarni, R. A., \& Saraswati, D. L. (2017). Pengembangan Media Pembelajaran Mobile Learning Berbasis Android pada Materi Sifat Koligatif Larutan. JRPK: Jurnal Riset Pendidikan Kimia, 7(2), 160-167. doi: https://doi.org/10.21009/jrpk.072.10

[Indonesian]

Athhibby, A. R. (2015). Pengembangan Media Pembelajaran Fisika Berbasis Animasi Flash Topik Bahasan Usaha Dan Energi. Jurnal Pendidikan Fisika, 3(2), 25-33. doi: https://doi.org/10.24127/jpf.v3i2.238 [Indonesian]

Budiyono, S. (2011). Manajemen Penelitian Pengembangan ( Research \& Development) Bagi penyususn Tesis dan Disertasi. Yogyakarta : Aswaja Pressindo. [Indonesian]

Fridayanthie, E. W., \& Mahdiati, T. (2016). Rancang bangun sistem informasi permintaan ATK berbasis intranet (Studi kasus: Kejaksaan negeri Rangkasbitung). Jurnal Khatulistiwa Informatika, 4(2), 126-138. doi: https://doi.org/10.31294/jki.v4i2.1264

[Indonesian]

Herawati, N. S., \& Muhtadi, A. (2018). Pengembangan modul elektronik (e-modul) interaktif pada mata pelajaran Kimia kelas XI SMA. Jurnal Inovasi Teknologi Pendidikan, 5(2), 180-191. doi: https://doi.org/10.21831/jitp.v5i2.15424

[Indonesian]

Maison., Astalini, Kurniawan, D. A., \& Sholihah, L. R. (2018). Deskripsi Sikap Siswa Sma Negeri Pada Mata Pelajaran Fisika. Jurnal Edusains, 10(1), 160167.

https://core.ac.uk/download/pdf/294894286.pd f [Indonesian]

Moong, P. A., Sundaygara, C., \& Ayu, H. D. (2020). Pengaruh Model Pembelajarn MEA dengan Metode Scaffolding terhadap penguasaan konsep fisika ditinjau dari SRL. Jurnal Pendidikan Fisika, $3(1)$,

104-111. http://dx.doi.org/10.24127/jpf.v8i1.2258

[Indonesian]

Andi, Crtistian., Hesinto, Sebri., Agustina (2018). Rancang Bangun Website Sekolah Dengan Menggunakan Framework Bootstrap ( Studi Kasus SMP Negeri 6 Prabumulih ). Jurnal Sisfokom, 07(01), 22-27.

https://doi.org/10.32736/sisfokom.v7i1.278

[Indonesian]

Permanasari, A. (2016). STEM Education: Inovasi dalam Pembelajaran Sains. In Prosiding Seminar Nasional Pendidikan Sains (SNPS) 2016 (pp. 23-34). [Indonesian]

Priatna, I., Putrama, I., \& Divayana, D. (2017). Pengembangan E-Modul Berbasis Model Pembelajaran Project Based Learning Pada Mata Pelajaran Videografi untuk Siswa Kelas X Desain Komunikasi Visual di SMK Negeri 1 Sukasada. Jurnal Nasional Pendidikan Teknik Informatika : JANAPATI, 66(1), 70-78. doi:http://dx.doi.org/10.23887/janapati.v6i1.993 1 [Indonesian]

Rahayuningsih, P., \& Qohar, A. (2014). Analisis Kesalahan Menyelesaikan Soal Cerita Sistem Persamaan Linear Dua Variabel (Spldv) Dan Scaffolding-Nya Berdasarkan Analisis Kesalahan Newman Pada Siswa Kelas Viii Smp Negeri 2 Malang. Jurnal Pendidikan Matematika Dan Sains, 2(2), $\quad$ 109-116.

doi:

https://doi.org/10.21831/jpms.v4i2.7161 [Indonesian]

Rahmatiah, R., Koes, S., \& Kusairi, S. (2016). Pengaruh Scaffolding Konseptual dalam Pembelajaran Group Investigation Terhadap Prestasi Belajar Fisika Siswa SMA dengan Pengetahuan Awal Berbeda Pengaruh Scaffolding Konseptual dalam Pembelajaran Group Investigation. Jurnal Pendidikan Fisika Dan Teknologi, 2(2), 45-54. doi: https://doi.org/10.29303/jpft.v2i2.288 [Indonesian]

Rizkiyah, A. (2013). Penerapan Blended Learning untuk Meningkatkan Hasil Belajar Siswa pada Mata Pelajaran Ilmu Bangunan di Kelas X TGB SMK Negeri 7 Surabaya. Jurnal Kajian Pendidikan Teknik Bangunan, 1(1), 40-49. Retrieved from https://ejournal.unesa.ac.id/index.php/jurnalkajian-ptb/article/view/10264 [Indonesian]

Setiawati, R., Fatmaryanti, S. D., \& Ngazizah, N. (2013). Pengembangan Modul Berbasis Inkuiri Terbimbing untuk Mengoptimalkan Sikap Ilmiah Peserta Didik pada Pokok Bahasan Listrik Dinamis di SMA N 8 Purworejo Kelas X Tahun Pelajaran 2012/2013. Jurnal Radiasi, 3(1), 19-23. http://download.portalgaruda.org/article.php?a $\underline{\text { rticle }=97632 \& v a l=614}$ [Indonesian] 
Siahaan, M. (2020). Dampak pandemi covid-19 terhadap dunia pendidikan. Jurnal Kajian Ilmiah, 1(1).

http:/ / ejurnal.ubharajaya.ac.id/.ndex.php/JKI [Indonesian]

Subramaniam, M. M., Ahn, J., Fleischmann, K. R., \& Druin, A. (2012). Reimagining the Role of School Libraries in STEM Education: Creating Hybrid Spaces for Exploration. The Library Quarterly, 82(2), 161-182. https://doi.org/10.1086/664578

Sumiati, E., Septian, D., \& Faizah, F. (2018). Pengembangan modul fisika berbasis Scientific Approach untuk meningkatkan Keterampilan Proses Sains siswa Development of Scientific Approach-based physics modules to improve students ' Science Process Skills. Jurnal Pendidikan Fisika Dan Keilmuan (JPFK), 4(2), 75-88. doi: https:// doi.org/10.2572/jpfk.v4i2.2535 [Indonesian]

Supriyatun, S. E. (2019). Implementasi pembelajaran sains, teknologi, engineering, dan matematika STEM pada materi fungsi kuadrat. JUMLAHKU: Jurnal Matematika Ilmiah STKIP Muhammadiyah Kuningan, 5(1), 80-87. doi: https://doi.org/10.33222/jumlahku.v5i1.567 [Indonesian]

Tegeh, I. M., Jampel, I. N., \& Pudjawan, K. (2015). Pengembangan Buku Ajar Model Penelitian Analyze Implement Evaluate Design Develop. Seminar Nasional Riset Inovatif IV, 208-216. [Indonesian]

Yulia, S. R., \& Ramli, R. (2019). Analisis Kebutuhan Pengembangan Handout Berbasis STEM Terhadap Pembelajaran Fisika dalam Menghadapi Era Revolusi Industri 4.0. Jurnal Penelitian Pembelajaran Fisika, 5(1), 42-48 doi: https://doi.org/10.24036/jppf.v5i1.107420

[Indonesian] 